Журнал«Герстективита інновації наукиљ

(Серія«Гедагогіка», Серія«Гцихологія», Серія«Медицинв»

№(6) 2022

УДК $378.14+37.025$

https://doi.org/10.52058/2786-4952 -2022-1(6)-360-369

Ходикіна Юлія Юріївна кандидат психологічних наук доцент кафедри психологічної та педагогічної антропології факультет дошкільної освіти, Харківський педагогічний національний університет імені Г.С. Сковороди, вул. Алчевських, 29, м. Харків, https://orcid.org/0000-0002-0246-5421

Приймак Віктор Миколайович старший викладач кафедра технологічної та професійної освіти і декоративного мистецтва Хмельницький національний університет, вул. Інститутська, 11, м. Хмельницький, https://orcid.org/0000-0003-4421-5348

Поленкова Марина Володимирівна завідувачка кафедри креативних індустрій i соціальних інновацій доктор економічних наук, доцент Кафедра креативних індустрій і соціальних інновацій Факультет соціальних технологій, оздоровлення та реабілітації Національний університет «Чернігівська політехніка», вул. Шевченка, 95, м. Чернігів, 14035, https://orcid.org/0000-0002-1755-2624

Руденко Ольга Валентинівна кандидат філософських наук, доцент кафедра філософії та методології наук, Київський національний університет імені Тараса Шевченка, вул. Володимирська, 60, м. Київ, 01033, https://orcid.org/0000-0002-1755-2624

\title{
ФЕНОМЕН КЛІПОВОГО МИСЛЕННЯ У КОНТЕКСТІ ФОРМУВАННЯ ПРОФЕСІЙНОЇ КОМПЕТЕНТНОСТІ МАЙБУТНІХ ВИКЛАДАЧІВ ПСИХОЛОГО-ПЕДАГОГІЧНИХ ДИСЦИПЛІН
}

Анотація. У статті розглянуто феномен кліпового мислення крізь призму взаємної кореляції між технологічним прогресом та культурними перетвореннями у суспільстві. 3'ясовано, що в науково-педагогічній та психологічній літературі накопичено певний досвід щодо визначення означеного феномену, під яким розуміють процес відображення численних різноманітних властивостей об'єктів, без урахування зв'язків між ними, що може характеризуватися фрагментарністю, алогічністю, розрізненістю інформації. Зазначено неоднозначність i багатоаспектність феномену кліпового мислення та його вплив на різні сфери життя, зокрема на професійну підготовку в закладах вищої освіти.

Доведено, що кліпове мислення - це процес засвоєння та відтворення численних різноманітних властивостей об'єктів, без установлення взаємозв'язків між ними. Розкрито ключові характеристики кліпового 
мислення, серед яких: фрагментарність засвоюваного матеріалу, алогічність у сприйнятті та запам'ятовуванні інформації, різнорідність інформації, висока швидкість змін інформаційних фрагментів, що засвоюються, лабільність.

Висвітлено чинники кліпового мислення. Проаналізовано позитивні та негативні аспекти прояву кліпового мислення. Зосереджено увагу на функціонуванні означеного явища у контексті формування професійної компетентності майбутніх викладачів психолого-педагогічних дисциплін. Розглянуто означений феномен з боку успішності навчання, пошуку шляхів подолання його негативних факторів i оптимального застосування його переваг під час професійної підготовки майбутніх фахівців. Обгрунтовано багатофакторну детермінованість та необхідні умови подолання недоліків і зміцнення переваг означеного феномену.

Зроблено висновок, що в процесі формування професійної компетентності майбутніх викладачів психолого-педагогічних дисциплін необхідно враховувати сутнісні особливості феномену «кліпове мислення» 3 метою ефективного перебігу їхньої навчальної та пізнавальної діяльності. Акцентовано увагу на перегляді змістової складової навчального матеріалу, врахуванні індивідуально-психологічних особливостей здобувачів.

Ключові слова: кліпове мислення, професійна компетентність, майбутні викладачі психолого-педагогічних дисциплін

Khodykina Yuliia Yuriivna Candidate of Psychological Sciences Associate Professor of Psychological and Pedagogical Anthropology The Department of Psychological and Pedagogical Anthropology faculty preschool education H.S. Skovoroda Kharkiv National Pedagogical University, Alchevskyh St., 29, Kharkiv, https://orcid.org/0000-0002-0246-5421

Pryimak Viktor Mykolaiovych Senior Lecturer Department of Technological and Vocational Education and Decorative Arts Khmelnytsky National University Khmelnytsky, 11 Institutska St., Khmelnytsky, Institute St., 11, https://orcid.org/0000-0003-4421-5348

Polenkova Maryna Volodymyrivna Doctor of Economics, Associate Professor Head of the Department of Creative Industries and Social Innovation Faculty of Social Work, Health Improvement and Rehabilitation, Chernihiv Polytechnic National University, 95 Shevchenko St., Chernihiv, 14035, https://orcid.org/0000-0003-1571-6792

Rudenko Olga Valentynivna PhD, Associate Professor Department of Philosophy and Methodology of Sciences Taras Shevchenko National University of Kyiv Volodymyrska St., 60, Kyiv, https://orcid.org/0000-0002-1755-2624 
Журнал«Герспективита інновації наукиљ

(Серія«Гедагогіка», Серія«Гцихологія», Серія«Медицинв»

№1(6) 2022

\title{
THE PHENOMENON OF CLIP THINKING IN THE CONTEXT OF FORMATION OF PROFESSIONAL COMPETENCE OF FUTURE TEACHERS OF PSYCHOLOGICAL AND PEDAGOGICAL DISCIPLES
}

\begin{abstract}
The article considers the phenomenon of clip thinking through the prism of mutual correlation between technological progress and cultural transformations in society. It was found that there is some experience in defining this phenomenon in the scientific, pedagogical and psychological literature. It means the process of reflecting the many different properties of objects, without regard to the links between them, which may be characterized by fragmentary, illogical, disparate information. The ambiguity and multifaceted nature of the phenomenon of clip thinking and its impact on various spheres of life, in particular on professional training in higher education institutions, are noted.

It is proved that clip thinking is a process of assimilation and reproduction of many different properties of objects, without establishing relationships between them. The key characteristics of clip thinking are revealed. They include the fragmentary nature of the assimilated material, illogical perception and memorization of information, heterogeneity of information, high rate of change of assimilated information fragments, lability.

The factors of clip thinking are highlighted. The positive and negative aspects of the manifestation of clip thinking are analyzed. Attention is focused on the functioning of this phenomenon in the context of the formation of professional competence of future teachers of psychological and pedagogical disciplines. The mentioned phenomenon from the point of view of success of training, search of ways of overcoming its negative factors and optimal application of its advantages during professional training of future specialists is considered. Multifactorial determinism and necessary conditions for overcoming the shortcomings and strengthening the advantages of this phenomenon are substantiated.

It is concluded that it is necessary to take into account the essential features of the phenomenon of "clip thinking" in the process of forming the professional competence of teachers of psychological and pedagogical disciplines in order to effectively conduct their educational and cognitive activities. Emphasis is placed on reviewing the content of the educational material, taking into account the individual psychological characteristics of students.
\end{abstract}

Keywords: clip thinking, professional competence, future teachers of psychological and pedagogical disciplines.

Постановка проблеми. Збільшення уваги до системи професійних знань, пошуку інформації та появи новітніх інформаційних технологій викликало переорієнтацію сучасного суспільства та вихід на новий етап розвитку - інформаційно-комунікаційний.

Новостворений всесвітній глобальний простір забезпечує ефективну взаємодію людей, задовольняє численні потреби в різноманітних 
інформаційних продуктах та послугах, а також надає доступ до світових ресурсів, що відкриває безмежні можливості. Проте, така глобальна інформатизація призводить до змін в ментальному плані. Під впливом телебачення, безперешкодного доступу до Інтернет-ресурсів, комп'ютерних ігор, формується новий тип мислення, який отримав назву «кліпове».

Феномен означеного явища спричинив низку змін в традиційній системі сприйняття дійсності, що, в свою чергу, призвело до змін у всіх сферах життя. Зокрема, найбільшої уваги зосереджено на необхідності зміни традиційної освітньої парадигми сьогодення, оскільки вона досить повільно реагує на стрімкі зміни та вимоги сучасного суспільства. Внаслідок цього очевидним стає невідповідність очікувань майбутніх фахівців, які прийшли у заклади вищої освіти отримувати певну професію і вже володіють кліповим мисленням - традиційному підходу в системі фахової підготовки.

Аналіз останніх досліджень і публікацій. Термін «кліпове мислення» 3'явився в середині 90-х р.р. минулого століття, проте увійшов до активного вжитку та функціонуванню нещодавно. В науково-педагогічній та психологічній літературі вже накопичено певний досвід щодо визначення означеного феномену. Засновником аналізу терміну «кліпове мислення» вважають Е. Тоффлера [1], який розумів його як складову частину мислення в цілому, що формується під впливом інформаційних ресурсів [1].

Деякі науковці вважають кліпове мислення набутим видом мислення, завдяки якому людина здатна оперувати лише епізодами фіксованої довжини та не може працювати зі складними структурами [2]. Іншими словами, - це має вияв у тому, що людина не може протягом тривалого часу зосереджуватися на будь-якій інформації та глибоко аналізувати їі.

Низку досліджень присвячено соціально-психологічні аспектам кліпового мислення, серед яких увага акцентується на фрагментарності сприйняття, трансформації понятійного мислення на пріоритетність вражень тощо.

Дослідниця Т. Семеновських розуміє кліпове мислення як процес відображення численних різноманітних властивостей об'єктів, без урахування зв’язків між ними, що може характеризуватися фрагментарністю, алогічністю, розрізненістю інформації, яка надходить, високою швидкістю змін фрагментів, відсутністю цілісної картини сприйняття навколишнього світу [3]. Відповідно до такого тлумачення можна підсумувати, що кліпове мислення уособлює адаптацією людини до цифрової культури.

Отже, спираючись на наукову базу, можна зазначити неоднозначність i багатоаспектність означеного феномену, його вплив на різні сфери життя, зокрема на професійну підготовку в закладах вищої освіти. Оскільки мислення людини цифрової культури все більше спрямоване на сприйняття зорових i звукових образів, це призводить до зниження здатності до розмірковування, рефлексивності, тому що створені кліповим мисленням образи оцінюються не логічною складовою, а емоційно-чуттєвою [4]. 
Журнал«Герспективита інноваціїнукиљ

(Серія«Гердагогіка», Серія «Гиихологія», Серія «Медицина»

№(6) 2022

3 огляду на зміну системи мислення сучасного суспільства виникає необхідність перегляду презентації навчального матеріалу в закладах вищої освіти під час опанування майбутніми спеціалістами тим чи іншим фахом. Дослідниками розглядається цей феномен 3 боку успішності навчання, пошуку шляхів подолання його негативних факторів i оптимального застосування його переваг під час професійної підготовки майбутніх фахівців.

Мета статті - дослідження феномену кліпового мислення у контексті формування професійної компетентності майбутніх викладачів психологопедагогічних дисциплін.

\section{Виклад основного матеріалу.}

Аналіз останніх джерел і публікацій засвідчив, що кліпове мислення набуває поширення та стає масовим суспільним явищем, завдяки якому відбувається швидке засвоєння певного обсягу інформації різної тематики та, водночас, захист від інформаційних перевантажень.

Існує думка, що кліпове мислення - це мислення, вибудоване на сприйнятті матеріалу за зразками, що є принципово новим вектором у діаді «людина - інформаційний потік» [4].

Слід зазначити, що уніфікована дефініція кліпового мислення, що $\epsilon$ загально визнаною, - відсутня. Проте, систематизація поглядів дослідників на природу та сутність означеного явища, показує, що кліпове мислення - це процес засвоєння та відтворення численних різноманітних властивостей об'єктів, без установлення взаємозв'язків між ними.

До основних характеристик кліпового мислення належать такі [5]:

- фрагментарність матеріалу, що засвоюється та веде до відсутності цілісного сприйняття;

- ймовірна алогічність у сприйнятті та запам'ятовуванні інформації;

- різнорідність інформації, що надходить;

- висока швидкість змін інформаційних фрагментів, що засвоюються;

- лабільність.

Аналіз наукових джерел дозволяе виокремити низку чинників, що сприяли виникненню кліпового мислення [1]:

- зміна та нарощування темпів перебігу життєвих подій і процесів, які стають базисом зростання обсягу інформаційного потоку, що, в свою чергу, призводить до вибірковості у засвоєнні інформації, виокремлення пріоритетів у сприйнятті потрібного матеріалу та відфільтровування зайвого;

- потреба у найбільш актуальній і важливій інформації та значення швидкості їі отримання й надходження;

- збільшення різноманітності, розгалуженості інформаційного матеріалу, що надходить;

- необхідність виконувати декілька справ одночасно у зв'язку з темпами перебігу життєвих подій, що зростають; 
Оскільки феномен кліпового мислення - неоднозначний та багатогранний, можна виокремити позитивні та негативні його характеристики.

До переваг кліпового мислення можна віднести такі [6]:

- швидкість реакції, яка передбачає безпроблемне перемикання уваги 3 одного об'єкту на інший, що знижує навантаження на мозок, захищає від надлишкової та непотрібної інформації;

- здатність швидко адаптуватися до умов, які змінюються, та приймати рішення відповідно до певних ситуацій;

- легке залучення до роботи та здатність виконувати декілька справ одночасно;

- швидке сприйняття інформації у великому обсязі на основі виокремлення ключових моментів;

Проте існує думка, що досить швидка реакція на сприйняття інформації нівелює здатність глибокого проникнення у сутність явищ, які засвоюються. Тож, дослідниками виокремлюються певні недоліки кліпового мисленні, серед яких такі [6]:

- нетривала концентрація уваги на певній інформації;

- відсутність здатності глибоко занурюватися та детально аналізувати інформацію;

- складність у встановленні причинно-наслідкових зв'язків між явищами та поєднанні їх в систему;

- складність у формулюванні, аналізі та висловлюванні власних роздумів;

- схильність до попадання під чужий вплив або маніпуляції;

- зниження творчих здібностей;

- закритість для пізнання та створення нового, вузькоспрямованість;

- зниження рівня критичного мислення внаслідок надходження інформації у вигляді розрізнених фрагментів.

Виходячи 3 аналізу переваг і недоліків кліпового мислення слід звернути увагу на зміни в процесі підготовки майбутніх фахівців в закладах вищої освіти.

Підготовка майбутніх викладачів психолого-педагогічних дисциплін умовно складається 3 двох блоків: блок теоретичних дисциплін i блок дисциплін із практичною спрямованістю. Проте кожен з блоків передбачає засвоєння значної кількості навчального матеріалу. Отже, виникає суперечність між необхідністю опанування великого обсягу навчального матеріалу й здатністю студентів, зі сформованим кліповим мисленням, засвоїти цей матеріал. Звідси постає потреба у забезпеченні набуття професійної компетентності означених майбутніх фахівців в умовах сучасної трансформації способу сприйняття й засвоєння матеріалу. Освітніми стандартами підготовки майбутніх викладачів психолого-педагогічних дисциплін передбачено слідування певним умовам, зокрема чіткому дотриманню затверджених освітніх програм, та збільшенню частки самостійної роботи здобувачів, що спирається на стійку мотивацію до отримання професії. 
Методологічно гуманітарна освіта спирається, переважно, на засади компетентнісного підходу, відповідно до якого майбутній фахівець має володіти низкою сформованих компетенцій, які будуть забезпечувати йому якісне здійснення подальшої професійної діяльності [3]. Проте стандартне слідування принципам компетентнісного підходу може виявитися не повною мірою ефективним у зв'язку з трансформацією образу мислення. Доречним вбачається сконцентруватися на перевагах феномену «кліпове мислення» та здійснювати навчальний процес майбутніх фахівців, спираючись саме на них.

Отже, провідними засадами формування професійної компетентності майбутніх викладачів психолого-педагогічних дисциплін із урахуванням особливостей кліпового мислення можна вважати такі [7]:

1. Оперування здатністю швидко перемикати увагу з одного об'єкта на інший. Означений аспект буде сприяти розвитку творчого мислення, оскільки здобувач буде поставлений в умови необхідності оцінки отриманого завдання в цілому та його окремих складових частин. Названий аспект доречно застосовувати на початковому етапі навчання, коли істотне навантаження щодо вивчення теоретичних дисциплін.

2. Застосування здатності мислити фрагментарно, кадрами. Цей аспект також знадобиться під час опанування значної кількості інформації 3 дисциплін в діахронному аспекті.

3. Поєднання декількох шляхів сприйняття та засвоєння інформації: зорового (створення візуального ряду допоможе швидше засвоїти матеріал), слухового (пояснення викладача) тощо. Цей аспект доречний під час викладання як теоретичних, так і практичних дисциплін, зокрема історії педагогіки, психології і т.д. Проте тут значна роль відведена саме викладачу, від підготовки якого, буде залежати якісна розробка навчального заняття.

4. Акцент на асоціативності як інструменті перемикання розумового процесу з одного образу на інший. Такий чинник буде стимулювати розвиток креативності та нестандартності в сприйнятті й відтворенні образів, буде сприяти рефлексії. В процесі створення асоціативного ряду, здобувач досить легко може сформулювати власне бачення теми.

Висвітлені засади переорієнтації навчального процесу з урахуванням особливостей кліпового мислення можуть говорити й про зміну у формах навчального матеріалу, що пропонується [8].

Однією 3 традиційних форм презентації навчального матеріалу під час професійної підготовки майбутніх викладачів психолого-педагогічних дисциплін в закладах вищої освіти є лекція [3]. Доведено, що простий вербальний виклад матеріалу викладачем вже не $\epsilon$ ефективним та доцільним.

Отже, врахування особливостей кліпового мислення здобувачів дозволяє зазначити, що найбільш ефективним засобом запам'ятовування лекційної інформації стане застосування сучасних мультимедійних технологій, які дозволять формувати систему образів, на яких буде спиратися навчальний процес. Тому, актуальним $є$ укладання принципово нових електронних 
підручників, які мають не просто повторювати паперові носії, а містити окремі розділи-фрагменти 3 тем, що вивчаються, у вигляді анімації, відео, інтерактивні вправа, тощо [3].

Формування під час навчання образів із використанням сучасної комп'ютерної техніки не буде викликати складнощів. Тому, що можливе застосування слайдів або короткометражних анімаційних роликів [3]. Такий спосіб презентації інформації представляє собою своєрідний кліп. Проте не слід забувати, що кількість кліпів не повинна бути завеликою, а послідовність має бути обгрунтованою та логічною й асоціюватися у студентів 3 певними образами, що змінюють один одного.

Таким чином, пріоритетними у викладанні теоретичних блоків дисциплін можуть стати яскраві, чіткі та наочні презентації з зрозумілими образами та поняттями, які легко запам'ятовуються. Окремою перевагою можна вважати створення вузько-тематичних мікрофільмів або відеороликів із певними наочними прикладами, що ілюструють матеріал.

Отже, застосування інформаційно-комунікаційних технологій в навчальному процесі робить більш доступним та легким отримання необхідної інформації, звільняє як викладача, так і здобувача від низки зайвих операцій, створює умови для реалізації креативних здібностей учасників навчального процесу. Разом з тим, можуть виникати деякі складнощі, зокрема, можуть нівелюватися досить значимі складові - як-от можливість реалізації живого діалогічного спілкування між учасниками навчального процесу. Або зменшення ролі мови, як засобу об'єктивізації мислення людини, зниження необхідності користуватися живим мовленням для висловлення власної думки, що може призвести до проблем 3 формування професійної комунікативної компетентності [8].

Інтеграція інформаційно-комунікаційних технологій в освітній процес вимагає певних змін. Наприклад, переорієнтації ролі викладача. В навчальному процесі, який будується на урахуванні особливостей кліпового мислення, викладач - це не просто транслятор інформації, а тьютор, метою якого $\epsilon$ спрямування здобувачів на осмислення навчально-пізнавального процесу та обгрунтування його результатів під час здійснення навчальної діяльності [9].

Іншою дієвою формою навчальної роботи, в умовах врахування особливостей кліпового мислення, є складання кластерів 3 тем. Така форма роботи передбачає графічну організацію інформації, що відтворює смислові зв'язки між тим чи іншим явищем [2].

Також дієвою формою роботи 3 навчальним матеріалом $є$ застосування методики колективного аналізу конкретних (професійних) ситуацій або кейсметоду, що відкриває можливості до практичного застосування набутих теоретичних знань під час вивчення певної дисципліни. Безперечний міждисциплінарний характер означеного методу дозволяє актуалізувати й систематизувати усі отримані теоретичні знання із суміжних предметів [7]. 
Метод дозволяє реалізувати спільну творчу здобувачів, формує вміння й навички командної роботи, висловлювати та аргументувати власну позицію, аналізувати альтернативні погляди, тощо.

Висновки. Таким чином, під час формування професійної компетентності викладачів психолого-педагогічних дисциплін необхідно враховувати сутнісні особливості феномену «кліпове мислення» 3 метою ефективного перебігу їхньої навчальної та пізнавальної діяльності. Актуальним вважається перегляд змістової складової навчального матеріалу, акцентування на індивідуальнопсихологічних особливостях здобувачів. 3 метою продуктивного засвоєння матеріалу пропонується структурувати навчальний матеріал кліпами, змінювати форми та засоби презентації навчального матеріалу.

Особливість формування професійної компетентності майбутніх викладачів психолого-педагогічного профілю, 3 урахуванням феномену кліпового мислення, має полягати у формуванні та розвитку у здобувачів навичок i вмінь отримувати необхідну інформацію, а й сприймати іiі, аналізувати, критично осмислювати та раціонально застосовувати у подальшій професійній діяльності.

\section{Jimepamypa:}

1. Dautov. D. Features of clip thinking and attention among representatives of generations $X$ and generations Z. SHS Web of Conferences. №70. 2019. P.1-5

2. Солона Ю.О. Розроблення підходів щодо трансформації «кліпового» мислення майбутніх учителів біології способами організації навчально-дослідницької діяльності у фаховій підготовці. Інноващійна педагогіка. №13. 2019. С. 156-163

3. Семеновских Т.В. Феномен клипового мышления в образовательной вузовской среде. Науковедение. Эдукология и педагогика. № 5(24). 2014. С. 17-23.

4. Бхат С., Клиповое мышление - феномен цифровой культуры. Дом культуры. №4. 2021. C. 4.

5. Bukharbaeva A. Clip thinking of generation Z: methods of developing students' creative potential. Journal of Studies in Literature and Journalism. №25. 2020. P. 787-796.

6. Букатов В. М. Клиповые изменения в восприятии, понимании и мышлении современных школьников - досадное новообразование «постиндустриального уклада» или долгожданная реанимация психического естества? Актуальные проблемы психологического знания. №4 (49). 2018. С. 5-19.

7. Соболєва С. М. Кліпове мислення як соціально-психологічний феномен та його роль у навчально-пізнавальній діяльності студентів. Теорія і практика сучасної психології. №3. 2019. C. 86-90.

8. Літвінова М. Б. Досвід діагностування кліпового мислення. Педагогічні науки. №3 2017. C. 140-158.

9. Kornuta O. Clip thinking and clip perception: teaching methods aspect. Open educational e-environment of modern University. № 3. 2017. P. 75-79.

\section{References:}

1. Dautov, D. (2019). Features of clip thinking and attention among representatives of generations $\mathrm{X}$ and generations Z. SHS Web of Conferences, 70.1-5.

2. Solona, Yu. O. (2019). Rozroblennya pidkhodiv shchodo transformaciï «klipovogO» mislennya majbutnikh uchiteliv biologiï sposobami organizaciï navchal'no-doslidnic'koï 
diyal'nosti u fakhovij pidgotovci [Development of approaches to the transformation of "clip" thinking of future biology teachers by ways of organizing educational and research activities in professional training]. Innovacijna pedagogika - Innovative pedagogy, 13, 156-163 [in Ukrainian].

3. Semenovskikh, T.V. (2014). Fenomen klipovogo myshleniya v obrazovatel'noj vuzovskoj srede [The phenomenon of clip thinking in the educational university environment]. Naukovedenie. Ehdukologiya i pedagogika - Science. Educology and pedagogy, 5(24), 17-23 [in Russian].

4. Bkhat, S. (2021). Klipovoe myshlenie - fenomen cifrovoj kul'tury [Clip thinking is a phenomenon of digital culture]. Dom kul'tury - House of culture. 4. 4 [in Russian].

5. Bukharbaeva, A. (2020). Clip thinking of generation Z: methods of developing students' creative potential. Journal of Studies in Literature and Journalism, 25, 787-796.

6. Bukatov, V. M. (2018). Klipovye izmeneniya v vospriyatii, ponimanii i myshlenii sovremennykh shkol'nikov - dosadnoe novoobrazovanie «postindustrial'nogo uklada» ili dolgozhdannaya reanimaciya psikhicheskogo estestva? [Clip changes in perception, understanding and thinking of modern schoolchildren - an annoying new formation of a post-industrial order or a long-awaited resuscitation of the psychic nature?]. Aktual'nye problemy psikhologicheskogo znaniya - Actual problems of psychological knowledge, 4 (49), 5-19 [in Russian].

7. Soboleva, S. M. (2019). Klipove mislennya yak social'no-psikhologichnij fenomen ta jogo rol' u navchal'no-piznaval'nij diyal'nosti studentiv [Clip thinking as a socio-psychological phenomenon and its role in the educational and cognitive activities of students]. Teoriya i praktika suchasnoï psikhologiï - Theory and practice of modern psychology, 3, 86-90 [in Ukrainian].

8. Litvinova, M. B. (2017). Dosvid diagnostuvannya klipovogo mislennya [Experience in diagnosing clip thinking]. Pedagogichni nauki-Pedagogical sciences, 3, 140-158 [in Ukrainian].

9. Kornuta, O. (2017). Clip thinking and clip perception: teaching methods aspect. Open educational e-environment of modern University, 3, 75-79. 